\title{
Instytucja zarządu sukcesyjnego - nowe otwarcie dla przedsiębiorstwa osoby fizycznej?
}

\section{Streszczenie}

Jednoosobowa działalność gospodarcza jest najpopularniejszą formą prowadzenia działalności gospodarczej. Od ponad 30 lat obserwowany jest dynamiczny rozwój liczby przedsiębiorstw w Polsce. Jednocześnie Polacy są najszybciej starzejącym się społeczeństwem UE. W związku z powyższym w najbliższym czasie w wielu przedsiębiorstwach może wystąpić problem z zapewnieniem ciągłości funkcjonowania podmiotów gospodarczych w przypadku śmierci przedsiębiorców. W artykule podjęto próbę oceny implementacji instytucji zarządu sukcesyjnego przedsiębiorstwem osoby fizycznej do polskiego prawa w pierwszą rocznicę wprowadzenia nowych rozwiązań dla przedsiębiorców. W tym celu dokonano analizy jej wykorzystania przez przedsiębiorców.

Słowa kluczowe: zarząd sukcesyjny, jednoosobowa działalność gospodarcza, CEIDG, starzenie się społeczeństwa, ciągłość działalności gospodarczej

1 DrEwa M. Kwiatkowska-Akademia Leona Koźmińskiegow Warszawie; e-mail: ewcia@kozminski. edu.pl; ORCID: 0000-0001-7576-1996.

2 Arkadiusz Trela - ATR Consulting; e-mail: arkadiusz@trela.at; ORCID: 0000-0002-5282-7849. 


\title{
The Institution of Succession Management - a New Opening for a Natural Person's Enterprise?
}

\begin{abstract}
A sole proprietorship is the most common form of running a business. The number of enterprises operated in Poland has been growing dynamically for over 30 years. At the same time, the population of Poland is the fastest ageing society in the EU. In the light of the above, many enterprises may soon face the problem of maintaining business continuity in the event of death of their owners. The article attempts to evaluate the implementation of the institution of succession management of a natural person's enterprise into the Polish legal framework one year after new solutions were offered to Polish entrepreneurs. To this end, the way how entrepreneurs make use of this institution has been analysed.
\end{abstract}

Keywords: succession management, sole proprietorship, CEIDG, society ageing, business continuity 


\section{Wprowadzenie}

Wyzwaniem, nie tylko dla Polski, ale dla większości państw europejskich, jest starzenie się społeczeństw. W 2018 r. w Polsce ogółem było 38,4 mln ludzi, z czego ponad 6,7 mln osób w wieku $65+$, a osób w wieku $80+$ blisko 1,7 mln. Udział seniorów (osób w wieku 65+) w populacji wyniósł 17,5\% (tzw. wskaźnik starości), a osoby w wieku 80+ (tzw. grupa osób w sędziwym wieku) stanowiły 4,3\% społeczeństwa. Od $2000 \mathrm{r}$. nastąpił ponad 42-procentowy wzrost liczby osób starszych (w 2000 r. grupa wiekowa 65+ stanowiła 12,4\% ludności) ${ }^{3}$. Prognozy wskazują, że w 2070 r. w Polsce ma być ponad 33\% osób w wieku 65+ i ponad 16\% w wieku $80+{ }^{4}$. Co więcej, spośród krajów UE Polacy są najszybciej starzejącym się społeczeństwem. Zgodnie z prognozami Głównego Urzędu Statystycznego w 2020 r. liczba osób w wieku $60+$ zbliży się do $10 \mathrm{mln}$ i będzie stanowić ${ }^{1 / 4}$ ludności, zaś w 2030 r. przekroczy ona 10,7 mln (co stanowić ma 30\% ludności). Osób w wieku $80+$ w 2030 r. ma być już ponad 2,2 $\mathrm{mln}^{5}$. Powyższy trend oddziałuje na praktycznie wszystkie sfery życia. Wśród przedsiębiorców jest on również obserwowany.

Zachowanie ciągłości funkcjonowania jest nieodzowną kwestią związaną z każdą działalnością, w tym działalnością gospodarczą. Z reguły przedsiębiorca, rozpoczynając i następnie ją prowadząc, zakłada, że będzie ona trwałym bytem. Jednak działalność ta może napotykać na liczne trudności, m.in. te związane ze śmiercią przedsiębiorcy. Może to być szczególnie dotkliwe dla jednoosobowych działalności gospodarczych. W przypadku spólek kapitałowych śmierć wspólnika także może spowodować czasowy lub trwały brak możliwości podejmowania decyzji. Natomiast prawidłowo przeprowadzony proces sukcesji może pozwolić nie tylko na byt, ale również na rozwój rodzinnego biznesu w następnych pokoleniach ${ }^{6}$.

3 Główny Urząd Statystyczny, Ludność. Stan i struktura oraz ruch naturalny w przekroju terytorialnym w 2018 r. Stan w dniu 31 XII, Warszawa 2019, s. 16-18; Ibidem, Excel tablica 1. Ludność wedtug ptci i wieku w 2018 r. Stan w dniu 31 XII.

$4 \quad$ Komisja Europejska, Dyrekcja Generalna ds. Gospodarczych i Finansowych, The 2018 Ageing Report. Economic \& Budgetary Projections for the 28 EU Member States (2016-2070), Luxembourg 2018, s. 23.

5 Rada Ministrów, Strategia na rzecz Odpowiedzialnego Rozwoju do roku 2020 (z perspektywa do 2030 r.), Warszawa 2017, s. 149.

$6 \quad$ K. Wojarska-Aleksiejuk, P. Aleksiejuk, Ustawa o zarządzie sukcesyjnym w kontekście sukcesji firm rodzinnych w Polsce, "Nowy Przegląd Notarialny” 2019, 77(1), s. 43. 
25 listopada 2018 r. weszła w życie uchwalona 5 lipca 2018 r. ustawa o zarządzie sukcesyjnym przedsiębiorstwem osoby fizycznej ${ }^{7}$. Od tego dnia przedsiębiorcy prowadzący jednoosobową działalność gospodarczą uzyskali możliwość powoływania zarządcy sukcesyjnego. Instrument ten pozwala im na zdecydowanie o bycie prowadzonego przez siebie przedsiębiorstwa na wypadek własnej śmierci. Ustawodawca przewidział prostą i bezpłatną formę powołania zarządcy sukcesyjnego - zgłoszenia tego faktu choćby online w Centralnej Ewidencji i Informacji o Działalności Gospodarczej (CEIDG). W artykule dokonano analizy wykorzystania instytucji zarządu sukcesyjnego po roku obowiązywania nowych rozwiązań prawnych, co pozwoliło na podjęcie próby oceny jej implementacji.

\section{Przedsiębiorczość w polskiej rzeczywistości gospodarczej}

Dynamiczny rozwój liczby przedsiębiorstw w Polsce nastąpił po okresie gospodarki socjalistycznej dzięki tzw. ustawie Wilczka, czyli zupełnie nowym regulacjom określonym w ustawie z dnia 23 grudnia 1988 r. o działalności gospodarczej ${ }^{8}$. Ustawa, która weszła w życie 1 stycznia 1989 r., wprowadzała zasadę "co nie jest prawem zabronione, jest dozwolone". Artykuł 1 stanowił, że podejmowanie i prowadzenie działalności gospodarczej jest wolne i dozwolone każdemu na równych prawach, z zachowaniem warunków określonych przepisami prawa, a art. 4, że podmioty gospodarcze mogą $\mathrm{w}$ ramach prowadzonej działalności gospodarczej dokonywać czynności i działań, które nie są przez prawo zabronione. Ustawa ta jak na owe czasy była zaskakującym rozwiązaniem prawnym. Została ona bowiem wprowadzona jeszcze przez władze komunistyczne. Była wówczas jedną z najbardziej wolnorynkowych ustaw na świecie i spowodowała dynamiczny rozwój przedsiębiorczości od pierwszego dnia jej obowiązywania. Ostatecznie przestała obowiązywać 1 stycznia $2001 \mathrm{r}$. W tym czasie była nowelizowana 62 razy, zaś liczba obszarów działalności gospodarczej wymagających koncesji wzrosła z 11 do $202^{9}$.

W 2016 r. przedsiębiorstwa wypracowały 1,366 bln zł wartości dodanej brutto, co stanowi aż 73,6\% udziału w tworzeniu $\mathrm{PKB}^{10}$. Szczególnie istotną rolę w gospo-

7 Ustawa z dnia 5 lipca 2018 r. o zarządzie sukcesyjnym przedsiębiorstwem osoby fizycznej (Dz.U. z 2018 r., poz. 1629 z późn. zm.).

8 Ustawa z dnia 23 grudnia 1988 r. o działalności gospodarczej (Dz.U. Nr 41, poz. 324).

9 T. Grabarczyk, Zapomniana ustawa, czyli jak Mieczystaw Wilczek zreformował Polskę, http://www.civisliber.org/zapomniana-ustawa-czyli-jak-mieczyslaw-wilczek-zreformowal-polske/ (dostęp: 10.11.2019).

10 Polska Agencja Rozwoju Przedsiębiorczości, Raport o stanie sektora małych $i$ średnich przedsiębiorstw w Polsce, Warszawa 2019, s. 5. 
darce odgrywają mikro-, małe oraz średnie przedsiębiorstwa, a ich liczba systematycznie rośnie. Sektor przedsiębiorstw zdominowany jest przez mikroprzedsiębiorstwa. Stanowią one aż 96,5\% ogólu przedsiębiorstw w Polsce. Ich udział w tworzeniu PKB w 2016 r. wyniósł ponad 30\%. Przekłada się to na $40 \%$ wartości PKB generowanej przez przedsiębiorstwa. Co istotne z punktu widzenia sukcesji, $72,6 \%$ mikroprzedsiębiorstw działa 5 lat lub dłużej ${ }^{11}$. Rosnącą rolę sektora MŚP w gospodarce narodowej warto obserwować jednak przede wszystkim z perspektywy długofalowej. Udział tego sektora w generowaniu PKB wzrósł z około 30\% w połowie lat dziewięćdziesiątych do blisko 50\% w 2016 r. ${ }^{12}$. Przedsiębiorstwa, nie tylko kreują blisko 3/4 PKB w Polsce, ale odgrywają także istotną rolę na rynku pracy. Liczba pracujących $\mathrm{w}$ przedsiębiorstwach systematycznie rośnie i na koniec 2017 r. zbliżyła się do poziomu 9,9 mln osób, co stanowiło około 60\% spośród 16,5 mln pracujących w Polsce. Dominującą rolę na rynku zatrudnienia odgrywają duże przedsiębiorstwa z 42,5\% udziału w zatrudnieniu w 2017 r. Z grupy przedsiębiorstw mniejszych niż duże firmy największy udział w zatrudnieniu miały średnie przedsiębiorstwa (22\%), następnie mikroprzedsiębiorstwa $(20,5 \%)$ oraz przedsiębiorstwa małe $(15 \%)^{13}$.

Zgodnie z danymi rejestru REGON najpopularniejszą formą działalności gospodarczej w Polsce jest jednoosobowa działalność prowadzona przez osoby fizyczne. Na koniec 2016 r. wpisanych było w rejestrze prawie 3 mln osób fizycznych prowadzących działalność gospodarczą i blisko 300 tysięcy spółek cywilnych. Jednocześnie znajdowało się w nim tylko niewiele ponad 500 tys. spółek handlowych. Co więcej, w 2016 r. jednoosobową formę wykonywania działalności gospodarczej wybierało ponad 80\% zaczynających działalność gospodarczą ${ }^{14}$. W 2018 r., według danych Ministerstwa Przedsiębiorczości i Technologii firmy rodzinne stanowiły około 36\% wszystkich przedsiębiorstw w Polsce, generując 10\% PKB i zatrudniając połowę wszystkich pracowników ${ }^{15}$. Liczba wpisów osób fizycznych prowadzących działalność gospodarczą (łącznie ze wspólnikami spółek cywilnych) do CEIDG, wg danych NIK, w ciągu dwóch lat (2015-2017) wzrosła o 3,2\%, z 2,609 mln do 2,694 mln. Jednocześnie w tym samym okresie rosła, wg danych ZUS, liczba przedsiębiorców (podlegających wpisowi do CEIDG) wyrejestrowanych z ubez-

\footnotetext{
11 Ibidem, s. 10.

12 Ibidem, s. 5; Polska Fundacja Promocji i Rozwoju Małych i Średnich Przedsiębiorstw, Stan sektora matych $i$ średnich przedsiębiorstw w Polsce. Raport za lata 1995-1996, Warszawa 1997, s. 13.

13 Polska Agencja Rozwoju Przedsiębiorczości, Raport..., s. 6.

14 Uzasadnienie do rządowego projektu ustawy o zarządzie sukcesyjnym przedsiębiorstwem osoby fizycznej z projektami aktów wykonawczych, druk sejmowy nr 2293, Sejm VIII kad., s. 3.

15 Ministerstwo Przedsiębiorczości i Technologii, Sukcesja firm jednoosobowych. Ustawa o zarządzie sukcesyjnym przedsiębiorstwem osoby fizycznej. Praktyczny poradnik, Warszawa 2018, s. 9.
} 
pieczenia z powodu śmierci-odpowiednio 3,2 tys. w 2015 r., 3,3 tys. w 2016 r. i 3,9 tys. w $2017 \mathrm{r}$. Taki stan rzeczy pociągnął za sobą utratę zatrudnienia odpowiednio dla 6,8 tys. osób w 2015 r., 7 tys. w 2016 r. i 8,3 tys. w 2017 r. ${ }^{16}$. W 2017 r. średniomiesięcznie z powodu zgonu wykreślanych było 750 przedsiębiorców ${ }^{17}$. Dane te uzasadniają objęcie inicjatywą ustawodawczą i uregulowanie kwestii związanych z zarządem sukcesyjnym przedsiębiorstwem osoby fizycznej prowadzącej działalność gospodarczą na podstawie wpisu do CEIDG.

Problematyka zapewnienia ciągłości działalności gospodarczej rozpatrywana powinna być z punktu widzenia różnych grup interesariuszy. Oczywistym jest rozpatrywanie sukcesji jako narzędzia zachowania ciągłości biznesu z punktu widzenia przedsiębiorcy, a dokładniej z punktu widzenia spadkobierców przedsiębiorcy. Nie sposób pominąć jednakże znaczenia sukcesji z punktu widzenia rynku pracy oraz gospodarki narodowej. Zaburzenie ciągłości funkcjonowania na rynku może szczególnie dotykać segment mikroprzedsiębiorstw. Jednak należy pamiętać, że osoby fizyczne na podstawie wpisu do CEIDG mogą prowadzić działalność gospodarczą nie tylko w skali mikro, ale także na bardzo dużą skalę, osiągając wielomilionowe obroty ${ }^{18}$.

Do dnia wprowadzenia instytucji zarządu sukcesyjnego do polskiego prawa, śmierć przedsiębiorcy prowadzącego we własnym imieniu działalność gospodarczą, była równoznaczna z końcem bytu prowadzonego przez niego przedsiębiorstwa jako nierozerwalnie związanego ze zmarłym ${ }^{19}$. Dlatego też nieuwzględnienie potrzeby zapewnienia ciągłości funkcjonowania przedsiębiorstwa zmarłego przedsiębiorcy było przez lata problemem wielu podmiotów. W wielu przypadkach niepewność obrotu spowodowana długotrwałymi postępowaniami spadkowymi tworzyła okres swego rodzaju zawieszenia. Byt wielu podmiotów gospodarczych mógł być zagrożony ${ }^{20}$. Tym samym zagrożone były również miejsca pracy. Śmierć przedsiębiorcy oznaczała m.in.: wygaśnięcie NIP-u, problemy z rozliczeniami podatkowymi, trudności w dostępie do kont bankowych, wygaśnięcie decyzji administracyjnych, w tym: koncesji, licencji i zezwoleń, a także umów, w tym umów

16 Najwyższa Izba Kontroli, Informacja o wynikach kontroli: Działania organów państwa wobec problematyki dziedziczenia przedsiębiorstw, Warszawa 2018, s. 19-20.

17 Ibidem, s. 25.

18 Ibidem, s. 10; Polska Agencja Rozwoju Przedsiębiorczości, Weszła w życie ustawa o sukcesji - łatwiejsza zmiana pokoleniowa, 23.11.2018, https://www.parp.gov.pl/component/content/article/50377:wchodziw-zycie-ustawa-osukcesji-latwiejsza-zmiana-pokoleniowa-w-firmach (dostęp: 10.08.2019).

19 Ocena skutków regulacji do rządowego projektu ustawy o zarządzie sukcesyjnym przedsiębiorstwem osoby fizycznej z projektami aktów wykonawczych, druk nr 2293, Sejm VIII kad., s. 1.

20 J. Bieluk, Ustawa o zarządzie sukcesyjnym przedsiębiorstwem osoby fizycznej. Komentarz, Warszawa 2019, s. 2. 
o pracę ${ }^{21}$. Nie istniała możliwość nawet tymczasowego posługiwania się firmą przedsiębiorcy identyfikującą w obrocie prawnym jego samego, ale również prowadzone przez niego przedsiębiorstwo. Następcy prawni mogli wznowić działalność jedynie po uregulowaniu spraw spadkowych, rejestracji nowej działalności, pozyskaniu pracowników oraz uzyskaniu stosownych pozwoleń organów administracji publicznej. Swoista kontynuacja działalności po zmarłym, polegająca praktycznie na rozpoczęciu na nowo działalności, musiała więc być odsunięta w czasie ${ }^{22}$. Wobec powyższego zadziwiającym jest fakt, że problematyka zapewnienia ciągłości działalności gospodarczej po śmierci przedsiębiorcy była pomijana w regulacjach prawnych aż do czasu wprowadzenia w życie uchwalonej 5 lipca 2018 r. ustawy o zarządzie sukcesyjnym przedsiębiorstwem osoby fizycznej. Przedstawiając projekt tego rozwiązania, wnioskodawca podkreślał, że ma się ono przyczynić do zmniejszenia liczby przypadków, gdy śmierć właściciela przedsiębiorstwa osoby fizycznej, a także wspólnika spółki cywilnej powoduje nagłe i nieuporządkowane zakończenie działalności oraz komplikacje w gospodarce ${ }^{23}$. Przyjęte rozwiązania mają umożliwić kontynuowanie działalności do chwili uregulowania spraw spadkowych ${ }^{24}$.

\section{Zarząd sukcesyjny w polskim systemie prawnym}

Ustawa o zarządzie sukcesyjnym przedsiębiorstwem osoby fizycznej, w art. 1 „reguluje zasady tymczasowego zarządzania przedsiębiorstwem po śmierci przedsiębiorcy, który we własnym imieniu wykonywał działalność gospodarczą na podstawie wpisu do Centralnej Ewidencji i Informacji o Działalności Gospodarczej, zwanej dalej »CEIDG«, oraz kontynuowania działalności gospodarczej wykonywanej z wykorzystaniem tego przedsiębiorstwa"25. W uzasadnieniu do projektu ustawy o zmianie niektórych ustaw w celu ograniczenia obciążeń regulacyjnych wnioskodawca zaznaczył, że ustawa ta „odpowiadała na najważniejszy i najbar-

21 Ministerstwo Przedsiębiorczości i Technologii, Sukcesja firm jednoosobowych. Ustawa o zarzadzie sukcesyjnym przedsiębiorstwem osoby fizycznej. Prezentacja, Warszawa 2019, https://www.gov.pl/web/ rozwoj/sukcesja (dostęp: 28.10.2019).

22 Najwyższa Izba Kontroli, op. cit., s. 5 i 10.

23 Uzasadnienie do rządowego projektu ustawy o zarządzie..., s. 146.

24 Najwyższa Izba Kontroli, op. cit., s. 5.

25 Art. 1 ustawy z dnia 5 lipca 2018 r. o zarządzie sukcesyjnym przedsiębiorstwem osoby fizycznej (Dz.U. z 2018 r., poz. 1629). Tytuł powoływanej ustawy na mocy art. 66 pkt 1 ustawy z dnia 31 lipca 2019 r. o zmianie niektórych ustaw w celu ograniczenia obciążeń regulacyjnych (Dz.U. z 2019 r., poz. 1495), z dniem 1 stycznia 2020 r. zmieni się na: ustawa o zarządzie sukcesyjnym przedsiębiorstwem osoby fizycznej i innych ułatwieniach związanych z sukcesją przedsiębiorstw, zaś artykuł 1 zgodnie z art. 66 pkt 3 powołanej nowelizacji otrzyma oznaczenie art. 1 pkt. 1. 
dziej palący problem dotyczący sukcesji biznesu w związku ze śmiercią przedsiębiorcy wpisanego do CEIDG" ${ }^{26}$. Ustawodawca ograniczył obowiązywanie omawianych rozwiązań do podmiotów wpisanych do CEIDG. Taki zabieg ma służyć zapewnieniu bezpieczeństwa obrotu gospodarczego poprzez ujawnienie istnienia w przedsiębiorstwie zarządcy sukcesyjnego ${ }^{27}$. Ustawa ta umożliwia przedsiębiorcy wykonującemu we własnym imieniu działalność gospodarczą powołanie zarządcy sukcesyjnego na wypadek śmierci poprzez wskazanie określonej osoby do pełnienia funkcji zarządcy sukcesyjnego albo zastrzeżenie, że z chwilą śmierci wskazany prokurent nim się stanie (art. 9 ust. 1). Zgodnie z art. 9 ust. 2 powołanie zarządcy sukcesyjnego oraz wyrażenie zgody przez powołanego wymaga formy pisemnej pod rygorem nieważności. Następnie, zgodnie z art. 10, konieczne jest złożenie przez przedsiębiorcę wniosku o wpis do CEIDG zarządcy sukcesyjnego. Jest to alternatywne rozwiązanie dla tworzonych planów sukcesji, w których to następca przejmował przedsiębiorstwo jeszcze za życia przedsiębiorcy ${ }^{28}$. Z punktu widzenia ciągłości działalności gospodarczej wprowadzone rozwiązanie prawne jest trudne do przecenienia. Właściwie automatyczne zastąpienie przez zarządcę sukcesyjnego zmarłego przedsiębiorcy pozwala na możliwie niezakłócone funkcjonowanie podmiotu gospodarczego. Dzięki implementowaniu tej instytucji, byt przedsiębiorstwa zmarłego przedsiębiorcy nie ulega zawieszeniu. Zachowuje ono swój NIP, umowy z pracownikami nie wygasają, podobnie jak inne umowy, koncesje i zezwolenia ${ }^{29}$. Wzmocnieniu ulega ochrona praw interesariuszy związanych z funkcjonowaniem przedsiębiorstwa, w tym m.in. spadkobierców, pracowników, konsumentów, a także kontrahentów ${ }^{30}$. Możliwe staje się utrzymanie renomy, ochrona interesów powiązanych z bytem przedsiębiorstwa podmiotów ${ }^{31}$.

W przypadku, w którym przedsiębiorca za życia zgodnie z art. 6 ust. 1 powołał zarządcę sukcesyjnego, powołany wyraził zgodę na pełnienie tej funkcji i dokonany został odpowiedni wpis do CEIDG, to w chwili jego śmierci zgodnie z art. 7 ust. 1 pkt. 1 zostaje ustanowiony zarządca sukcesyjny. W jednym momencie funkcję zarządcy sukcesyjnego może pełnić jedna osoba (art. 11 ust. 1). Jednak przedsiębiorca powołując zarządcę sukcesyjnego na wypadek własnej śmierci może także,

26 Uzasadnienie do rządowego projektu ustawy o zmianie niektórych ustaw w celu ograniczenia obciążeń regulacyjnych, druk sejmowy nr 3622, Sejm VIII kad., s. 2.

27 Uzasadnienie do rządowego projektu ustawy o zarządzie..., s. 12.

28 Ibidem, s. 18.

29 Ministerstwo Przedsiębiorczości i Technologii, Sukcesja firm jednoosobowych. Ustawa o zarządzie sukcesyjnym przedsiębiorstwem osoby fizycznej. Prezentacja...

30 Uzasadnienie do rządowego projektu ustawy o zarządzie..., s. 8.

31 K. Kopaczyńska-Pieczniak, Status prawny zarządcy sukcesyjnego, „Przegląd Prawa Handlowego”, 2018,12 , s. 6. 
zgodnie z art. 11 ust. 2, powołać tzw. zarządcę rezerwowego, który w sytuacji braku możliwości wykonywania swoich funkcji przez powołanego w pierwszej kolejności wejdzie na jego miejsce.

Istnieje możliwość ustanowienia zarządcy sukcesyjnego nawet w sytuacji, $\mathrm{w}$ której przedsiębiorca nie skorzystał $\mathrm{z}$ rozwiązania przewidzianego $\mathrm{w}$ art. 9 i nie powołał zarządcy sukcesyjnego za swojego życia lub nie dochował obowiązków wynikających z art. 10, czyli nie złożył odpowiedniego wniosku o wpis do CEIDG. W takiej sytuacji, aby powołanie zarządcy sukcesyjnego było skuteczne, musi być sporządzone $\mathrm{w}$ formie aktu notarialnego. Uprawnione, enumeratywnie wskazane w art. 12 ust. 1 i 2 do tego osoby mają dwa miesiące od dnia śmierci przedsiębiorcy na powołanie zarządcy sukcesyjnego (art. 12 ust. 10). Bieg tego terminu nie może być przywrócony ${ }^{32}$.

$\mathrm{W}$ przypadku, $\mathrm{w}$ którym $\mathrm{w}$ wyniku śmierci przedsiębiorcy został ustanowiony zarząd sukcesyjny, wpisowi do CEIDG podlega, zgodnie z art. 5 ust. 1 pkt 2a ustawy o Centralnej Ewidencji i Informacji o Działalności Gospodarczej i Punkcie Informacji dla Przedsiębiorcy ${ }^{33}$, oznaczenie „w spadku”. Zgodnie z art. 17 ust. 1 ustawy o zarządzie sukcesyjnym „w sprawach wynikających z prowadzenia przedsiębiorstwa w spadku zarządca sukcesyjny posługuje się dotychczasową firmą przedsiębiorcy z dodatkiem oznaczenia „w spadku”. Dla kontrahentów i innych zainteresowanych taki dodatek w firmie oznacza, że przedsiębiorca będący właścicielem przedsiębiorstwa zmarł, a jego przedsiębiorstwo jest prowadzone przez zarządcę sukcesyjnego.

Zgodnie z art. 2 ust. 1 ustawy o zarządzie sukcesyjnym „przedsiębiorstwo w spadku obejmuje składniki niematerialne i materialne, przeznaczone do wykonywania działalności gospodarczej przez przedsiębiorcę, stanowiące mienie przedsiębiorcy w chwili jego śmierci". Ustęp 4 powoływanego przepisu stanowi, że "(...) przepisy ustawy odnoszące się do przedsiębiorstwa w spadku stosuje się odpowiednio do udziału przedsiębiorcy w majątku wspólników spółki cywilnej". Ustawowe rozwiązania stanowią zatem narzędzie mogące zapewnić przedsiębiorstwom osoby fizycznej i spółkom cywilnym możliwość niezakłóconego funkcjonowania na wypadek śmierci przedsiębiorcy. Pojęcie przedsiębiorstwa w spadku odnosi się do okresu od śmierci przedsiębiorcy do chwili wygaśnięcia odpowied-

32 P. Blajer, Zarząd sukcesyjny przedsiębiorstwem osoby fizycznej. Pytania i odpowiedzi. Wzory pism. Przepisy, Warszawa 2019, s. 62-63.

33 Ustawa z dn. 6 marca 2018 r. o Centralnej Ewidencji i Informacji o Działalności Gospodarczej i Punkcie Informacji dla Przedsiębiorcy (t.j. Dz.U z 2019 r., poz. 1291 z późn. zm). 
nio: zarządu sukcesyjnego (w przypadku jego ustanowienia) lub uprawnienia do powołania zarządu sukcesyjnego (w przypadku jego niepowołania) ${ }^{34}$.

Obowiązkiem zarządcy sukcesyjnego jest prowadzenie przedsiębiorstwa zmarłego, czyli przedsiębiorstwa w spadku (art. 18). Nie wykonuje on jednak działalności gospodarczej w rozumieniu przepisów prawa przedsiębiorców, gdyż nie działa na swój rachunek ${ }^{35}$, a jedynie zastępuje właściciela czyli działa na rzecz spadkobierców przedsiębiorstwa w spadku. Zgodnie z art. 21 ust. 1 „zarządca sukcesyjny działa w imieniu własnym, na rachunek właściciela przedsiębiorstwa w spadku”. Dokonuje on czynności zwykłego zarządu (art. 22 ust. 1). Jego działalność skutkuje zmianami w majątku przedsiębiorstwa w spadku ${ }^{36}$.

Instytucja zarządu sukcesyjnego stanowi rozwiązanie tymczasowe. Zarząd sukcesyjny wygasa m.in. z upływem 2 lat (art. 59 ust. 1 pkt. 7), a Sąd, z ważnych przyczyn, może go przedłużyć na czas nie dłuższy niż 5 lat od dnia śmierci przedsiębiorcy (art. 60 ust. 1). W ustawie nie przewidziano instrumentów umożliwiających trwałe przekazanie przedsiębiorstwa następcom prawnym. Nawet po zastosowaniu omawianej instytucji ostatecznie konieczne będzie rozpoczęcie przez spadkobierców działalności gospodarczej na własny rachunek.

\section{Zarząd sukcesyjny w praktyce}

W CEIDG znajduje się ponad 2,379 mln aktywnych przedsiębiorców ${ }^{37}$. Konieczność sukcesji przedsiębiorstwa na wypadek śmierci przedsiębiorcy prowadzącego jednoosobową działalność gospodarczą może dotknąć każdego z nich. Co oczywiste, jest to najbardziej prawdopodobne w przypadku najstarszych przedsiębiorców. Według danych CEIDG ponad 220 tys. aktywnych przedsiębiorców ukończyło 65 rok życia (co stanowi ponad 9\% wszystkich aktywnych wpisów w rejestrze), a ponad 414 tys. -60 rok życia (co stanowi ponad $17 \%$ aktywnych podmiotów) $)^{38}$. Strukturę wiekową aktywnych przedsiębiorców przedstawiono w tabeli 1.

\footnotetext{
34 J. Bieluk, op. cit., s. 12.

35 Zgodnie z art. 3 ustawy z dnia 6 marca 2018 r. Prawo przedsiębiorców (t.j. Dz.U. z 2019 r., poz. 1292 z późn. zm.) „Działalnością gospodarczą jest zorganizowana działalność zarobkowa, wykonywana we własnym imieniu i w sposób ciągły".

36 M. Sieradzka, Zarząd sukcesyjny przedsiębiorstwem osoby fizycznej - analiza i ocena nowych rozwiąań prawnych (cz. I), „Monitor Prawniczy” 2018, 22, s. 1199.

37 Niepublikowane dane z bazy przedsiębiorców CEIDG (stan na dzień 7.11.2019).

38 Ibidem.
} 
Tabela 1. Wiek aktywnych przedsiębiorców

\begin{tabular}{cc}
\hline wiek przedsiębiorców & odsetek aktywnych przedsiębiorców \\
\hline $18-24$ & 2,4 \\
$25-34$ & 19,9 \\
$35-44$ & 29,3 \\
$45-54$ & 22,2 \\
$55-64$ & 16,9 \\
$65+$ & 9,3 \\
\hline
\end{tabular}

Źródło: opracowanie własne na podstawie danych CEIDG (stan na dzień 7.11.2019).

W ciągu ponad 9 miesięcy obowiązywania ustawy o zarządzie sukcesyjnym, czyli od 25 listopada 2018 r. do końca sierpnia 2019 r., w wyniku śmierci z rejestru przedsiębiorców zostało wykreślonych ponad 7 tysięcy podmiotów ${ }^{39}$. Miesięcznie wykreślanych jest więc $\mathrm{z}$ tego powodu średnio około 785 przedsiębiorców. Ponad $61 \% \mathrm{z}$ nich stanowią osoby w wieku $60+$. Przedstawiona w tabeli 2 struktura wieku przedsiębiorców wykreślonych z CEIDG wskutek śmierci wskazuje, że blisko 45\% tych przedsiębiorców było w wieku 65+. Drugą co do liczebności grupą były osoby w wieku 55-64 (27,5\%). Dane te potwierdzają oczywisty wniosek - im starsi przedsiębiorcy, tym wyższe jest prawdopodobieństwo ich śmierci. Jednocześnie jednak wskazują, jak palącym problemem jest zapewnienie sukcesji, szczególnie w podmiotach gospodarczych ściśle powiązanych z osobą właściciela.

Tabela 2. Odsetek przedsiębiorców wykreślonych z CEIDG wskutek śmierci

\begin{tabular}{cc}
\hline wiek przedsiębiorców & $\begin{array}{c}\text { odsetek przedsiębiorców wykreślonych } \\
\text { wskutek śmierci }\end{array}$ \\
\hline $18-24$ & 0,6 \\
$25-34$ & 3,5 \\
$35-44$ & 8,6 \\
$45-54$ & 15,0 \\
$55-64$ & 27,5 \\
$65+$ & 44,7 \\
\hline
\end{tabular}

Źródło: opracowanie własne na podstawie danych CEIDG (stan na dzień 7.11.2019).

39 Niepublikowane dane z bazy przedsiębiorców CEIDG (dane za okres grudzień 2018 - sierpień 2019). 
W ciągu blisko roku funkcjonowania ustawy o zarządzie sukcesyjnym (od 25 listopada 2018 r. do 6 listopada 2019 r.) jedynie 10864 przedsiębiorców powołało, zgodnie z art. 9 ust. 1 ustawy, zarządcę sukcesyjnego na wypadek własnej śmierci ${ }^{40}$. Oznacza to, że mniej niż pół procenta $(0,46 \%)$ przedsiębiorców skorzystało z wprowadzonego przed blisko rokiem rozwiązania ustawowego. Przewidziana przez ustawodawcę możliwość zabezpieczenia ciągłości działalności przedsiębiorstwa na wypadek własnej śmierci nie znalazła więc właściwie wielkiego odzewu wśród przedsiębiorców. Co nie powinno zaskakiwać, odsetek przedsiębiorców, którzy w omawianym okresie powołali zarządcę sukcesyjnego, jest tym wyższy im są oni starsi. Niemniej jednak nawet w przedziale $65+$ jedynie 1,11\% przedsiębiorców powołało zarządcę sukcesyjnego (tabela 3).

Tabela 3. Struktura wieku przedsiębiorców, którzy powołali zarządców sukcesyjnych

\begin{tabular}{ccc}
\hline wiek przedsiębiorców & $\begin{array}{c}\text { odsetek przedsiębiorców, którzy } \\
\text { powołali zarządcę sukcesyjnego }\end{array}$ & $\begin{array}{c}\text { liczba przedsiębiorców, którzy } \\
\text { powołali zarządcę sukcesyjnego }\end{array}$ \\
\hline $18-24$ & 0,07 & 40 \\
$25-34$ & 0,15 & 688 \\
$35-44$ & 0,31 & 2170 \\
$45-54$ & 0,47 & 2472 \\
$55-64$ & 0,76 & 3041 \\
$65+$ & 1,11 & 2453 \\
\hline
\end{tabular}

Źródło: opracowanie własne na podstawie danych CEIDG (stan na dzień 7.11.2019).

Wśród osób najstarszych, czyli tych w wieku 80+, odsetek przedsiębiorców, którzy skorzystali z omawianego rozwiązanie był taki sam jak wśród wszystkich seniorów (1,11\%). Warto zauważyć, że wśród najmłodszych przedsiębiorców, osób w wieku 18-24 lata, zaledwie 40 powołało zarządcę sukcesyjnego. Dodatkowo, w CEIDG zostało wpisanych 918 zarządców rezerwowych ${ }^{41}$. Niecałe 8,5\% przedsiębiorców, którzy powołali zarządcę sukcesyjnego, powołało też, zgodnie $\mathrm{z}$ art. 11 ust. 2, tzw. zarządcę rezerwowego.

Od dnia wejścia w życie ustawy do końca sierpnia 2019 r. zmarło 7207 przedsiębiorców. W 8,7\% przypadków ustanowiono zarządcę sukcesyjnego. Jedynie w 151 przypadkach (24,1\% przypadków ustanowienia zarządcy sukcesyjnego) zarządca sukcesyjny został powołany, zgodnie z art. 9 ust. 1, przez przedsiębiorców

\footnotetext{
40 Niepublikowane dane z bazy przedsiębiorców CEIDG (stan na dzień 7.11.2019).

41 Ibidem.
} 
jeszcze za ich życia. Taki sposób powołania zarządcy sukcesyjnego oznacza, że $\mathrm{w}$ chwili zgonu przedsiębiorcy automatycznie zostaje ustanowiony zarządca sukcesyjny. Pomimo wprowadzenia nowych rozwiązań prawnych, zdecydowana większość zarządców sukcesyjnych $(75,9 \%)$ została powołana, zgodnie z art. 12 , już po śmierci przedsiębiorcy przez uprawnione, wymienione $w$ art. 12 ust. 1 i 2 do tego osoby i następnie, zgodnie $\mathrm{z}$ art. 7 ust. 1 pkt. 2, ustanowiona z chwilą dokonania przez notariusza wpisu do CEIDG. W 13,9\% zarządca był ustanowiony w ciągu pierwszych 7 dni, zaś w 70,8\% przypadków w ciągu 30 dni od śmierci przedsiębiorcy. W pozostałych przypadkach zarząd sukcesyjny ustanowiono $\mathrm{w}$ przewidzianym w art. 12 ust. 10 terminie 2 miesięcy. Taki stan rzeczy może wskazywać na dostrzeżenie przez spadkobierców korzyści wynikających ze skorzystania z omawianego rozwiązania. Jednak z punktu widzenia ciągłości funkcjonowania podmiotów gospodarczych ten sposób ustanawiania zarządcy sukcesyjnego jest mniej pożądany. Istnieje bowiem luka czasowa - pewien okres, w którym w wyniku śmierci przedsiębiorcy może wystąpić brak ciągłości w działalności przedsiębiorstwa osoby fizycznej.

\section{Podsumowanie}

Powszechne stosowanie ogólnie obowiązujących rozwiązań prawnych w zakresie instytucji zarządu sukcesyjnego może zapewnić ciągłość prowadzonej działalności i obniżyć ryzyko utraty sprawności zarządczej przedsiębiorstwem w wypadku śmierci przedsiębiorcy. Według oceny skutków regulacji przedstawionych wraz z projektem ustawy o zarządzie sukcesyjnym instytucja zarządu sukcesyjnego przyczynić się miała do zmniejszenia liczby przypadków, w których śmierć przedsiębiorcy będącego właścicielem przedsiębiorstwa osoby fizycznej lub wspólnikiem spółki cywilnej powoduje nagłe i nieuporządkowane zakończenie prowadzenia działalności gospodarczej. Powinno to skutkować zmniejszeniem związanych ze zgonem komplikacji występujących w obrocie gospodarczym. Projektodawca wskazywał, że przedsiębiorcy wykazywali duże zainteresowanie sukcesją ${ }^{42}$. Przeprowadzone w 2016 r. badanie ankietowe ${ }^{43}$ wskazało dostrzeżenie problemu sukcesji u $94 \%$ przedsiębiorców. Ponad 68\% badanych wskazało na umożliwienie prowadzenia przedsiębiorstwa po śmierci przedsiębiorcy w niezmienionej formie, z tą samą

\footnotetext{
42 Ocena skutków regulacji..., s. 10.

43 Badanie ankietowe "Nowe rozwiązania prawne dla firm” przeprowadzone przez PARP na zlecenie MPiT w dniach 13-23 maja $2016 \mathrm{r}$.
} 
firmą (nazwą), nr REGON i NIP, jako najlepsze rozwiązanie kwestii sukcesji ${ }^{44}$. Wyniki tych badań nie znajdują jednak odzwierciedlenia w zaobserwowanej rzeczywistości. Przed wejściem w życie ustawy m.in. na stronie PARP została zamieszczona informacja dotycząca omawianego rozwiązania. Zachęcała ona przedsiębiorców do powoływania zarządców sukcesyjnych. Ponadto Ministerstwo Przedsiębiorczości i Technologii udostępniło na ten temat poradnik, jak również wysyłało maile do przedsiębiorców i pełnomocników ${ }^{45}$. Pomimo prowadzonych działań informacyjnych w ciągu roku funkcjonowania instytucji zarządu sukcesyjnego aktywność przedsiębiorców w zakresie wykorzystywania tego rozwiązania była jednak iluzoryczna. Prowadzenie akcji edukacyjno-informacyjnej spotkało się z niewielkim odzewem wśród przedsiębiorców. Mniej niż 0,5\% z nich powołało zarządcę sukcesyjnego za swojego życia. Co więcej tylko 8,5\% spośród nich powołało tzw. zarządcę rezerwowego. Liczby te wskazują na niski poziom zainteresowania omawianą instytucją lub na brak wiedzy i świadomości co do możliwego rozwiązania prawnego. Mogą również wskazywać na, w rzeczywistości błędne, przekonanie przedsiębiorców co do trudności związanych z przeprowadzaniem tej procedury. Mogą wreszcie oznaczać problem ze wskazaniem przez przedsiębiorców osoby, która w przypadku ich śmierci mogłaby tymczasowo poprowadzić przedsiębiorstwo w spadku. Jednak kto, jeśli nie przedsiębiorca zaangażowany w działalność gospodarczą jest w stanie zdecydować o osobie godnej reprezentowania go po śmierci. Ze względu na niski stopień wykorzystania możliwości powołania zarządcy sukcesyjnego wskazana wydaje się intensyfikacja prowadzonych działań informacyjnych, nastawionych zarówno na budowanie świadomości istnienia tego rozwiązania, jak i komunikujących jego prostotę.

Co prawda zarząd sukcesyjny przedsiębiorstwem osoby fizycznej odpowiada na potrzeby zapewniania ciągłości działalności gospodarczej w przypadku śmierci właściciela przedsiębiorstwa, to jednak problem ciągłości działalności może się także pojawić w sytuacji, gdy właściciel przedsiębiorstwa nie umrze, ale ulegnie ciężkiemu wypadkowi lub wskutek choroby czy zdarzenia losowego straci świadomość. Na wypadek wystąpienia takiej sytuacji konieczne jest wcześniejsze zabezpieczenie bytu podmiotu gospodarczego przez ustanowienie prokury. Instytucja zarządu sukcesyjnego nie znajdzie bowiem w takiej sytuacji zastosowania, a zarządzanie przedsiębiorstwem osoby fizycznej może okazać się niemożliwe.

Z powodu starzenia się społeczeństwa, a tym samym coraz większego udziału osób starszych wśród przedsiębiorców prowadzających działalność gospodarczą, instytucja zarządu sukcesyjnego może być coraz bardziej użyteczna. Powinna ona

\footnotetext{
44 Najwyższa Izba Kontroli, op. cit., s. 11 i 28.

45 Polska Agencja Rozwoju Przedsiębiorczości, Weszła w życie...
} 
być stosowana powszechnie. Ustawodawca mógłby rozważyć wprowadzenie obowiązku powoływania przez przedsiębiorcę zarządcy sukcesyjnego na wypadek śmierci. Ewentualnie obowiązek ten mógłby zostać wyłączony jedynie przez oświadczenie woli wskazujące na rezygnację z zastosowania tej instytucji. Takie rozwiązanie mogłoby podnieść odsetek przypadków, w których po śmierci przedsiębiorcy działalność jego przedsiębiorstwa byłaby kontynuowana.

\section{Bibliografia}

Bieluk J., Ustawa o zarządzie sukcesyjnym przedsiębiorstwem osoby fizycznej. Komentarz, Warszawa 2019.

Blajer P., Zarząd sukcesyjny przedsiębiorstwem osoby fizycznej. Pytania i odpowiedzi. Wzory pism. Przepisy, Warszawa 2019.

Główny Urząd Statystyczny, Ludność. Stan i struktura oraz ruch naturalny w przekroju terytorialnym w 2018 r. Stan w dniu 31 XII, Warszawa 2019.

Grabarczyk T., Zapomniana ustawa, czyli jak Mieczysław Wilczek zreformowat Polskę, http:// www.civisliber.org/zapomniana-ustawa-czyli-jak-mieczyslaw-wilczek-zreformowalpolske/ (dostęp: 10.11.2019).

Komisja Europejska, Dyrekcja Generalna ds. Gospodarczych i Finansowych, The 2018 Ageing Report. Economic \& Budgetary Projections for the 28 EU Member States (2016-2070), Luxembourg 2018.

Kopaczyńska-Pieczniak K., Status prawny zarządcy sukcesyjnego, „Przegląd Prawa Handlowego" 2018, 12, s. 4-11.

Ministerstwo Przedsiębiorczości i Technologii, Sukcesja firm jednoosobowych. Ustawa o zarządzie sukcesyjnym przedsiębiorstwem osoby fizycznej. Praktyczny poradnik, Warszawa 2018.

Ministerstwo Przedsiębiorczości i Technologii, Sukcesja firm jednoosobowych. Ustawa o zarzadzie sukcesyjnym przedsiębiorstwem osoby fizycznej. Prezentacja, Warszawa 2019, https://www.gov.pl/web/rozwoj/sukcesja (dostęp: 28.10.2019).

Najwyższa Izba Kontroli, Informacja o wynikach kontroli: Działania organów państwa wobec problematyki dziedziczenia przedsiębiorstw, Warszawa 2018.

Ocena skutków regulacji do rządowego projektu ustawy o zarządzie sukcesyjnym przedsiębiorstwem osoby fizycznej z projektami aktów wykonawczych, druk sejmowy nr 2293, Sejm VIII kad.

Polska Agencja Rozwoju Przedsiębiorczości, Raport o stanie sektora matych $i$ średnich przedsiębiorstw w Polsce, Warszawa 2019.

Polska Agencja Rozwoju Przedsiębiorczości, Weszła w życie ustawa o sukcesji - łatwiejsza zmiana pokoleniowa, 23.11.2018, https://www.parp.gov.pl/component/content/article/50377:wchodzi-w-zycie-ustawa-osukcesji-latwiejsza-zmiana-pokoleniowa-w-firmach (dostęp: 10.08.2019). 
Polska Fundacja Promocji i Rozwoju Małych i Średnich Przedsiębiorstw, Stan sektora matych i średnich przedsiębiorstw w Polsce. Raport za lata 1995-1996, Warszawa 1997.

Rada Ministrów, Strategia na rzecz Odpowiedzialnego Rozwoju do roku 2020 (z perspektywa do 2030 r.), Warszawa 2017.

Sieradzka M., Zarząd sukcesyjny przedsiębiorstwem osoby fizycznej - analiza i ocena nowych rozwiazań prawnych (cz. I), „Monitor Prawniczy” 2018, 22, s. 1195-1203.

Uzasadnienie do rządowego projektu ustawy o zarządzie sukcesyjnym przedsiębiorstwem osoby fizycznej z projektami aktów wykonawczych, druk sejmowy nr 2293, Sejm VIII kad.

Uzasadnienie do rządowego projektu ustawy o zmianie niektórych ustaw w celu ograniczenia obciążeń regulacyjnych, druk sejmowy nr 3622, Sejm VIII kad.

Wojarska-Aleksiejuk K., Aleksiejuk P., Ustawa o zarządzie sukcesyjnym w kontekście sukcesji firm rodzinnych w Polsce, „Nowy Przegląd Notarialny” 2019, 77(1), s. 43-67. 